\title{
An Estimation of Effective Mutagen Doses, Induced Genetic Variation and Characters Association in $\mathbf{M}_{2}$ Generation of Okra
}

\author{
Rajkumari Ashadevi $^{1}$, A.V.V. Koundinya ${ }^{2 *}$ and S.B. Chattopadhyay ${ }^{1}$ \\ ${ }^{1}$ Department of Vegetable Crops, Bidhan Chandra Krishi Viswavidyalaya, \\ Mohanpur, Nadia, West Bengal, India \\ ${ }^{2}$ Division of Crop Improvement, ICAR-CTCRI, Sreekaryam, Trivandrum, Kerala, India \\ *Corresponding author
}

\section{A B S T R A C T}

The experiment was done with two mutagenic agents viz., Gamma radiation $(\gamma)$ and EMS and two varieties namely BCO-1 and Japanese Jhar Bhendi. Seeds were irradiated with gamma rays at $100,200,300,400,500 \mathrm{kR} \gamma$ and treated with $0.1,0.2,0.3,0.4$ and 0.5 per cent EMS concentration. A total of 10gamma irradiated lines and 10 EMS treated lines along with dry and wet controls of the two varieties were grown in $\mathrm{M}_{2}$ generation. The first

Keywords

Mutation,

Okra, Comparison

of mutagens,

Genetic variation

and characters

association

Article Info

Accepted:

19 April 2017

Available Online:

10 May 2017 two principle components having Eigen values more than one were cumulatively contributing $99.57 \%$ to the total induced variation. The PC-1 associated with $300 \mathrm{kR} \gamma$, $400 \mathrm{kR} \gamma, 500 \mathrm{kR} \gamma, 0.3 \%$ EMS, 0.4\% EMS and 0.5\% EMS was contributing highly $52.86 \%$ to the variation. Both the mutagens ( $\gamma$ and EMS) induced more variation at higher doses than at their lower doses. Dendrogram explained that the mutagenic treatments could be distinguished into four different groups when less than $5 \%$ variation was considered.The treatments $100 \mathrm{kR} \gamma$ and $0.2 \%$ EMS were found to be highly diverse from the rest of the treatments. Both gamma irradiation and soaking in EMS caused sufficiently high GCV and PCV for effective selection to carry out in the characters as the first node to fruit, the number of flowers per plant, the number of fruits per plant and the number of seeds per pod and seed index. High heritability coupled with high GAM was observed for days to first flower set, first node to flower, first node to fruit, number of flowers per plant, number of fruits per plant, number of seeds per pod, seed index and fruit yield per plant in both the populations and for number of primary branches/plant when treated with gamma radiation; for fruit length when soaked in EMS suggesting that these characters were under strong influence of additive gene action. Positive association of fruit yield per plant with the number of flowers per plant and number of fruits per plant and negative association with days to first flower set and first fruiting node in both populations suggesting importance of these characters while selecting high yielding genotypes.

\section{Introduction}

Okra is one of the important vegetables of the tropical and subtropical regions of the world and is native to tropical Africa. Okra is highly nutritious and grown during summer and rainy seasons in all parts of the country. India is the largest producer of okra with the area, production and productivity of 0.53 Mha, 6.35 Mt and 11.9 t/ha respectively for the year 2013-14 (Anonymous, 2015). Okra has tremendous export potential as a fresh vegetable. It accounts for 70 per cent of the 30 per cent exchange earnings other than 
onion, from the export of vegetables (Anonymous, 2000). The young tender pods of okra are being used as a fresh vegetable, canned, dehydrated and frozen product. Selection of superior germplasm is based on the extent of genetic variation present in the available germplasm. Selection within local types exercised for a long time exhausted the natural genetic variability of the crop. Under such circumstances, induced mutagenesis can be efficiently employed as an alternative to induce the variability in different quantitative characters (Reddy and Dhaduk, 2014).

Inducing variation through mutation is common and has been found as successful in okra. The special use of induced mutations is basically to improve polygenic traits in crop plants by introducing desirable mutants directly into commercial cultivars, or use them indirectly through cross breeding (Jadhav et al., 2013).

Gamma radiation and Ethyl Methane Sulfonate (EMS) are the most commonly used mutagens in crop improvement programmes. Estimation of total induced variation through various genetic parameters gives an idea about the selection efficiency of different mutagenic treatments and studying the association between the characters helps in the formulation of selection criteria in a mutagenic generation in okra.

Keeping these points in view the present experiment was formulated with the following objectives. To find out the mutagenic treatments (dosages) that induced maximum variance based on Principle Component Analysis. And to compare the two mutagens namely gamma radiation and EMS based on the extent of genetic variation induced and their selection efficiency. Also to study the association of characters in both the gamma radiation and EMS-induced $\mathrm{M}_{2}$ generations in okra.

\section{Materials and Methods}

The experiment was carried out at Horticultural Research Farm, Mondouri, BCKV, Mohanpur, W.B. during the rainy season 2014. Two okra cultivars namely BCO-1 and Japanese JharBhendi seeds were irradiated with gamma rays at 100, 200, 300, $400,500 \mathrm{kR} \gamma$ and treated with $0.1,0.2,0.3$, 0.4 and 0.5 per cent EMS (Ethyl Methane Sulphonate) concentration. A total of 10 lines gamma irradiated and 10 EMS treated lines selected from $M_{1}$ generation along with dry and wet controls of the two varieties were grown in $\mathbf{M}_{2}$ generation, and data were collected regarding 16 growth and yield characters. Individual lines were sown in Randomized Block Design with three replications a spacing of $45 \times 30 \mathrm{~cm}$. All the recommended cultural practices were followed to maintain good crop stand throughout the experimentation. The Principle Components (PCs) were calculated by using the method suggested by Gower (1966). Ward's minimum variance technique was utilised for grouping of treatments by using mean values as per Ward (1963). Phenotypic and genotypic coefficients of variability, broad sense heritability $\left(\mathrm{h}^{2}\right)$ and expected genetic advance were estimated as suggested by Burton (1952), Hanson et al., (1956) and Johnson et al., (1955) respectively. Pearson correlation coefficients were worked out as per Singh and Chaudhary (1985).

\section{Results and Discussion}

The analysis of variance study indicated that significant variation was observed among the various gamma radiation treatments as well as EMS treatments of the two okra varieties viz., BCO-1 and Japanese Jhar Bhendi for all the characters under study. This result clarifies that both gamma radiation and EMS treatment are efficient in inducing sufficient variation in the okra varieties. Significant induced 
variation for various characters in $\mathrm{M}_{2}$ generation was previously observed in various okra varieties by Dhankhar and Dhankhar (2003) for leaf size, plant height and fruit size; Jadhav et al., (2012) for germination per cent; Jadhav et al., (2013) for plant height, days to $50 \%$ flowering, fruit length, fruit yield per plant and seeds per fruit; Reddy and Dhaduk (2014) for plant height, days to flowering, fruit length, fruit diameter, fruit number, fruit yield per plant, seeds per fruit; Kashid and Khulte (2014) for pod length.

Principle component analysis (Table 1) indicated that the first two components having Eigen values more than one were cumulatively contributing $99.57 \%$ variation. The PC-1 loaded with $300 \mathrm{kR} \gamma(0.641), 400$ $\mathrm{kR} \gamma$ (0.653), $500 \mathrm{kR} \gamma(0.694), 0.3 \%$ EMS (0.655), 0.4\% EMS (0.718) and 0.5\% EMS (0.746) was contributing $52.86 \%$ variation suggesting that the higher doses of both gamma radiation and EMS soaking created maximum variation. The PC-2 loaded with $100 \mathrm{kR} \gamma(0.763), 200 \mathrm{kR} \gamma(0.630), 0.1 \%$ EMS (0.642) and0.2\% EMS (0.716) was contributing $46.71 \%$ variation indicating lower doses of gamma radiation and EMS soaking induced slightly lesser variation compared with higher doses.

The graph (Fig. 1) and the dendrogram (Fig. 2), presented here, were explaining the classification of various mutagenic treatments based on the type of variation they induced. The mutagenic treatments can be distinguished into four different groups at less than $5 \%$ variation (Fig. 2). The treatments in each cluster were thought to induce a similar type of variation and they were diverse with the treatments in other groups. Thus, the three treatments $300 \mathrm{kR} \gamma, 400 \mathrm{kR} \gamma$ and $0.3 \% \mathrm{EMS}$ in group-I induced a similar type of variation. Similarly, other similar treatments were fallen in different groups as $200 \mathrm{kR} \gamma$ and $0.1 \%$ EMS in group-II; $500 \mathrm{kR} \gamma, 0.4 \%$ EMS and
$0.5 \%$ EMS in group-III; and $100 \mathrm{kR} \gamma$ and $0.2 \%$ EMS in group-IV (Fig. 1 and Fig. 2). When $25 \%$ variation was considered on dendrogram scale (Fig. 2), the treatments $100 \mathrm{kR} \gamma$ and $0.2 \%$ EMS differed from the rest of the treatments. It can be seen through the distantly placed positions of $100 \mathrm{kR} \gamma$ and $0.2 \%$ EMS on the graph (Fig. 1) suggesting that these two treatments were highly diverse with other treatments.

The perusal of table 2 indicates that slighter difference in the mean performance of the two sets of mutagenic populations namely gamma radiation induced and EMS-induced. However, germination percentage, plant height at 60 DAS, number of primary branches/plant, first node to flower, first node to fruit, number of flowers per plant and number of seeds per pod were found to be numerically high with gamma irradiation while plant height at 25 DAS, days to first flower set, days to first fruit set, number of epicalyx segments and important yield components like number of fruits per plant, fruit weight including fruit yield per plant were observed as high with soaking in various concentrations of EMS. Both gamma radiation and EMS treatments induced the same fruit length and seed index.

The numerically high germination percentage in case of gamma radiation than EMS treatment was previously observed by Jadhav et al., (2012). A higher number of seeds per fruit were found with gamma radiation (45 $\mathrm{kR}$ ) by Jadhav et al., (2013) in support of the present study. Contrary to present results, Jadhav et al., (2013) showed the lesser number of days to $50 \%$ flowering, lower fruit length and lower fruit yield per plant with EMS treatments rather than gamma radiation in $\mathrm{M}_{2}$ generation. Increase in pod length was found with EMS treatment (0.01 and 0.15\%) than gamma radiation in Parbhani Kranti variety of okra in $\mathrm{M}_{2}$ generation but, gamma 
rays (5 kR and $20 \mathrm{kR}$ ) induced longer fruit length in case of Arka Anamika (Kashid and Khulte, 2014).

Minor differences were observed between genotypic and phenotypic variance for all the characters in both the cases suggesting that role of the environment was less in phenotypic expression of the traits. It can be seen through high heritability values of all the characters in both sets of the treatments. Gamma radiation induced high variation for the characters like plant height, number of primary branches/plant, number of flowers per plant, number of fruits per plant, fruit weight and number of seeds per pod than soaking in EMS, which induced high variation for the characters like germination percentage, days to first flower set, days to first fruit set, number of epicalyx segments and fruit length. Both the mutagens induced the similar amount of variation in $\mathrm{M}_{2}$ generation for the characters namely first node to flower, the first node to fruit, seed index and fruit yield per plant.

GCV, PCV values provide a better depiction of induced variation through various mutagenic agents. Smaller differences were observed between GCV and PCV indicating that the influence of environment was low on the expression of these traits. When the extent of variation induced by both the mutagenic agents was compared, gamma irradiation induced high GCV and PCV values in the traits like plant height, number of primary branches/plant, number of flowers per plant, number of fruits per plant, fruit weight and number of seeds per pod, while soaking in EMS-induced higher GCV and PCV values in germination percentage, first node to fruit, number of epicalyx segments and fruit length. The magnitude of the difference between gamma radiation induced GCV-PCV and EMS-induced GCV-PCV was less for the characters like days to first flower set, days to first fruit set, the first node to flower, seed index and fruit yield per plant.

Both gamma irradiation and soaking in EMS caused sufficiently high GCV and PCV for effective selection to carry out in the characters as the first node to fruit, the number of flowers per plant, the number of fruits per plant, number of seeds per pod and seed index. Moderate GCV and PCV was induced for the traits like days to first flower set, the first node to flower and fruit yield per plant. Number of primary branches/plant recorded average GCV and PCV values when variation was induced by gamma radiation and low GCV and PCV values when EMS induced variation. Reversely, average GCV and PCV values were observed for fruit length when treated with EMS and low GCV and PCV values were observed when treated with gamma irradiation. Remaining traits had lower GCV and PCV values in both the cases suggesting the induction of insufficient variation for these characters.

The highest genotypic coefficient of variation and phenotypic coefficient of variation were observed for number of fruits per plant, yield per plant and plant height in a gamma radiation and EMS-induced okra population by Singh et al., (1998). High EMS at 0.2, 0.35 and $0.5 \%$ and diethyl sulphate (DES) at $0.025,0.07$ and $0.125 \%$ induced genetic variation for average fruit length, fruits per plant and fruit weight was observed in an $\mathbf{M}_{2}$ generation in okra by Suryakumari (2002). High genotypic and phenotypic coefficients of variation were found for number of fruits, and yield per plant in EMS treated $\mathrm{M}_{2}$ generation by Singh and Singh (2004). Very low gamma radiation and EMS-induced GCV values were observed for all the morphological and yield parameters such as days to flowering, plant height, number of branches per plant, number of nodes on the main stem, internodal length, fruit length, fruit diameter, fruit weight, 
number of seeds per fruit, number of fruits per plant, fruit yield per plant in $\mathrm{M}_{2}$ generation in $G O-2$ and $G J O-3$ varieties of okra by Reddy and Dhaduk (2014).

As said earlier, lower environmental variance resulted in high heritability of all the traits under study in both the cases of gamma irradiation and soaking in EMS except in fruit weight where moderate heritability due to EMS-induced variation was observed. The high heritability values of various characters viz., germination per cent, plant height 25 DAS, plant height 60 DAS, number of primary branches/plant, days to first flower set, days to first fruit set, first node to flower, first node to fruit, number of flowers per plant, number of fruits per plant, number of epicalyx segments, fruit length, number of seeds per pod, seed index and fruit yield per plant suggesting the high inheritance and repeatability of these characters in $\mathrm{M}_{3}$ generation.

High heritability for average fruit length, fruits per plant and fruit weight were observed in an $\mathrm{M}_{2}$ generation in okra by Suryakumari (2002). Reddy and Dhaduk (2014) reported high heritability for fruit yield per plant with all the gamma radiation treatments in $G O-2$ okra and high heritability for some fruits per plant with $0.25 \%$ EMS while remaining characters exhibited a moderate range of heritability in $\mathrm{M}_{2}$ generation.

The values of genetic advance as per cent of mean were higher for plant height at $25 \mathrm{DAS}$, plant height at $60 \mathrm{DAS}$, number of primary branches per plant, number of flowers per plant, number of fruits per plant, fruit weight, number of seeds per pod and fruit yield per plant when variation was induced by gamma irradiation rather than soaking in EMS. The values of genetic advance as per cent of mean were higher for germination percentage, days to first flower set, days to first fruit set, first node to flower, first node to fruit, number of epicalyx segments, fruit length and seed index when variation was induced by soaking in EMS rather than gamma irradiation.

Higher GAM (>20\%) was observed for days to first flower set, first node to flower, first node to fruit, number of flowers per plant, number of fruits per plant, number of seeds per pod, seed index and fruit yield per plant when variation was induced by both gamma radiation and soaking in EMS.

Table.1 Eigen values, percentage of variation and cumulative variation and factor loadings of two PCs

\begin{tabular}{|l|c|c|c|l|}
\hline PCs & $\begin{array}{c}\text { Eigen } \\
\text { values }\end{array}$ & $\begin{array}{c}\text { \% of } \\
\text { Variance }\end{array}$ & $\begin{array}{c}\text { Cumulative } \\
\%\end{array}$ & \multicolumn{1}{c|}{ Factor loadings } \\
\hline 1 & 5.286 & 52.86 & 52.86 & $\begin{array}{l}300 \mathrm{kR} \gamma(0.641), 400 \mathrm{kR} \gamma(0.653), 500 \mathrm{kR} \gamma \\
(0.694), 0.3 \% \text { EMS }(0.655), 0.4 \% \text { EMS }(0.718) \\
\text { and 0.5\% EMS }(0.746)\end{array}$ \\
\hline 2 & 4.671 & 46.71 & 99.57 & $\begin{array}{l}100 \mathrm{kR} \gamma(0.763), 200 \mathrm{kR} \gamma(0.630), 0.1 \% \text { EMS } \\
(0.642) \text { and } 0.2 \% \text { EMS }(0.716)\end{array}$ \\
\hline
\end{tabular}


Table.2 Mean performance and other genetic parameters of gamma radiation $(\mathrm{G})$ and $\mathrm{EMS}(\mathrm{E})$ induced $\mathrm{M}_{2}$ generation in okra

\begin{tabular}{|c|c|c|c|c|c|c|c|c|c|c|c|c|c|c|c|c|}
\hline \multirow{2}{*}{ Characters } & \multicolumn{2}{|c|}{ Mean } & \multicolumn{2}{|c|}{ GV } & \multicolumn{2}{|c|}{ PV } & \multicolumn{2}{|c|}{$\mathrm{GCV}$} & \multicolumn{2}{|c|}{ PCV } & \multicolumn{2}{|c|}{$h^{2}(b s)$} & \multicolumn{2}{|c|}{ GA } & \multicolumn{2}{|c|}{ GAM } \\
\hline & G & $\mathrm{E}$ & G & $\mathrm{E}$ & G & $\mathrm{E}$ & G & $\mathrm{E}$ & G & $\mathrm{E}$ & G & $\mathrm{E}$ & G & $\mathrm{E}$ & G & $\mathrm{E}$ \\
\hline Germination (\%) & 74.3 & 73.6 & 47.0 & 54.1 & 49.7 & 56.6 & 9.22 & 10.0 & 9.48 & 10.2 & 94.59 & 95.6 & 13.74 & 14.8 & 18.48 & 20.1 \\
\hline Plant height @ 25 DAS (cm) & 33.0 & 34.1 & 7.70 & 2.3 & 8.2 & 2.8 & 8.38 & 4.5 & 8.66 & 4.9 & 93.63 & 81.6 & 5.51 & 2.8 & 16.70 & 8.3 \\
\hline Plant height @60 DAS (cm) & 56.5 & 56.3 & 32.0 & 13.2 & 33.5 & 14.7 & 10.00 & 6.5 & 10.25 & 6.8 & 95.32 & 90.3 & 11.37 & 7.1 & 20.12 & 12.6 \\
\hline $\begin{array}{l}\text { Number of primary } \\
\text { branches/plant }\end{array}$ & 11.4 & 10.3 & 3.20 & 0.9 & 3.2 & 0.9 & 15.69 & 9.0 & 15.86 & 9.3 & 97.98 & 94.7 & 3.64 & 1.9 & 32.00 & 18.1 \\
\hline Days to first flower set & 41.8 & 43.8 & 22.5 & 25.1 & 23.3 & 26.0 & 11.34 & 11.5 & 11.56 & 11.6 & 96.25 & 96.8 & 9.58 & 10.2 & 22.93 & 23.2 \\
\hline Days to first fruit set & 49.8 & 50.6 & 21.4 & 24.9 & 22.6 & 26.1 & 9.31 & 9.9 & 9.57 & 10.1 & 94.66 & 95.7 & 9.28 & 10.1 & 18.65 & 19.9 \\
\hline First node to flower & 4.20 & 3.8 & 0.51 & 0.51 & 0.52 & 0.52 & 17.18 & 18.7 & 17.32 & 18.8 & 98.36 & 98.6 & 1.46 & 1.5 & 35.10 & 38.2 \\
\hline First node to fruit & 3.80 & 3.7 & 0.7 & 1.0 & 0.7 & 1.0 & 21.74 & 26.8 & 21.85 & 26.9 & 99.07 & 99.3 & 1.71 & 2.0 & 44.59 & 55.1 \\
\hline No. of flowers per plant & 8.00 & 7.9 & 3.7 & 2.5 & 3.7 & 2.6 & 24.00 & 20.1 & 24.11 & 20.2 & 99.10 & 99.0 & 3.94 & 3.3 & 49.21 & 41.2 \\
\hline No. of fruits per plant & 6.50 & 6.9 & 1.8 & 0.9 & 1.8 & 0.9 & 20.32 & 13.8 & 20.44 & 13.9 & 98.81 & 97.9 & 2.72 & 1.9 & 41.61 & 28.1 \\
\hline No. of epicalyx segments & 9.60 & 10.1 & 0.4 & 0.78 & 0.5 & 0.83 & 6.79 & 8.7 & 7.14 & 9.0 & 90.57 & 94.5 & 1.28 & 1.8 & 13.32 & 17.5 \\
\hline Fruit weight (g) & 5.70 & 5.90 & 0.19 & 0.01 & 0.21 & 0.02 & 7.61 & 1.3 & 7.93 & 2.4 & 92.30 & 50.0 & 0.86 & 0.1 & 15.07 & 1.4 \\
\hline Fruit length $(\mathrm{cm})$ & 6.40 & 6.40 & 0.3 & 0.8 & 0.4 & 0.8 & 9.07 & 14.1 & 9.36 & 14.3 & 93.83 & 97.7 & 1.15 & 1.9 & 18.10 & 28.7 \\
\hline No. of seeds per pod & 33.6 & 32.6 & 108.8 & 101.2 & 109.4 & 101.9 & 31.04 & 30.8 & 31.12 & 30.9 & 99.44 & 99.3 & 21.43 & 20.6 & 63.76 & 63.3 \\
\hline Seed index (g) & 7.50 & 7.5 & 2.8 & 2.87 & 2.9 & 2.9 & 22.49 & 22.7 & 22.60 & 22.8 & 99.03 & 99.2 & 3.45 & 3.5 & 46.11 & 46.6 \\
\hline Fruit yield per plant (g) & 37.0 & 40.7 & 31.2 & 30.8 & 31.8 & 31.5 & 15.11 & 13.7 & 15.27 & 13.8 & 97.95 & 97.8 & 11.38 & 11.3 & 30.80 & 27.8 \\
\hline
\end{tabular}

$\mathrm{G}=$ gamma radiation: $\mathrm{E}=\mathrm{EMS}$ soaking 
Table.3 Pearson correlation coefficient values between characters of gamma-radiated (below diagonal)

EMS treated (above diagonal) $\mathrm{M}_{2}$ populations

\begin{tabular}{|c|c|c|c|c|c|c|c|c|c|c|c|c|c|c|c|c|}
\hline & 胥 & 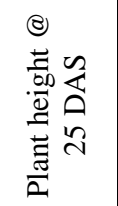 & 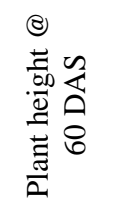 & 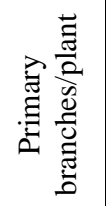 & 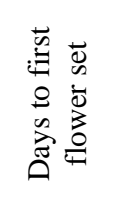 & 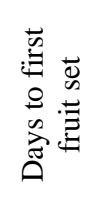 & 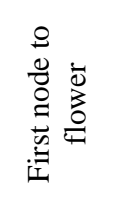 & 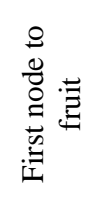 & 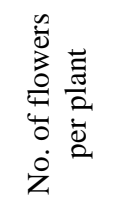 & 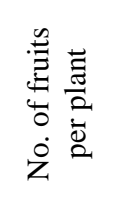 & 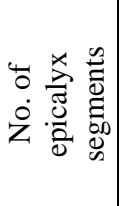 & 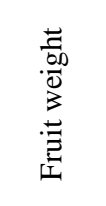 & 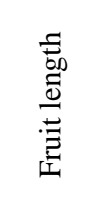 & 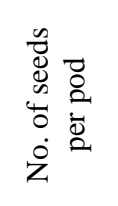 & 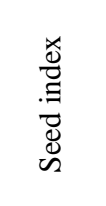 & 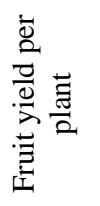 \\
\hline Germination (\%) & & $0.735^{*}$ & $0.760 *$ & 0.164 & -0.004 & $0.669 *$ & -0.145 & $0.818^{*}$ & -0.278 & -0.311 & 0.136 & -0.014 & 0.109 & $0.694 *$ & -0.549 & -0.318 \\
\hline Plant height @ 25 DAS & $0.656^{*}$ & & $0.939 *$ & 0.157 & $-0.631 *$ & 0.553 & $-0.701 *$ & 0.494 & 0.032 & -0.077 & -0.191 & 0.344 & -0.112 & 0.331 & -0.241 & -0.033 \\
\hline Plant height @60 DAS & $0.881 *$ & 0.479 & & 0.382 & -0.497 & $0.717 *$ & -0.585 & $0.604 *$ & 0.044 & 0.030 & -0.060 & 0.373 & -0.157 & 0.315 & -0.285 & 0.078 \\
\hline Primary branches/plant & 0.229 & 0.454 & 0.284 & & 0.216 & 0.555 & 0.140 & 0.277 & -0.070 & 0.137 & $0.624 *$ & 0.214 & -0.066 & 0.071 & 0.152 & 0.163 \\
\hline Days to first flower set & $-0.872 *$ & -0.351 & $-0.665^{*}$ & -0.017 & & 0.022 & $0.948 *$ & 0.203 & -0.420 & -0.282 & $0.645^{*}$ & -0.487 & 0.403 & 0.306 & -0.179 & -0.352 \\
\hline Days to first fruit set & 0.006 & 0.043 & -0.037 & 0.020 & -0.059 & & -0.122 & $0.815^{*}$ & 0.066 & 0.186 & 0.276 & 0.101 & 0.204 & $0.589 *$ & -0.430 & 0.193 \\
\hline First node to flower & $-0.699 *$ & -0.111 & -0.552 & 0.116 & $0.876^{*}$ & 0.321 & & 0.012 & -0.486 & -0.386 & 0.511 & -0.394 & 0.290 & 0.243 & -0.245 & -0.444 \\
\hline First node to fruit & -0.356 & -0.166 & -0.414 & -0.240 & 0.294 & $0.657 *$ & 0.532 & & -0.116 & -0.087 & 0.402 & 0.006 & 0.239 & $0.645^{*}$ & -0.494 & -0.093 \\
\hline No. of flowers per plant & 0.364 & -0.317 & 0.215 & -0.476 & $-0.692 *$ & -0.154 & $-0.789 *$ & -0.208 & & $0.853^{*}$ & -0.112 & -0.254 & -0.041 & -0.567 & 0.112 & $0.824 *$ \\
\hline No. of fruits per plant & 0.264 & -0.417 & 0.171 & -0.542 & $-0.625^{*}$ & -0.037 & $-0.697^{*}$ & 0.005 & $0.941 *$ & & -0.035 & -0.105 & -0.033 & -0.444 & 0.210 & $0.991 *$ \\
\hline No. of epicalyx segments & -0.024 & 0.164 & 0.008 & 0.409 & 0.165 & 0.148 & 0.265 & 0.528 & -0.419 & -0.273 & & -0.218 & 0.305 & 0.147 & 0.033 & -0.069 \\
\hline Fruit weight & 0.165 & $0.638^{*}$ & 0.251 & 0.499 & 0.202 & 0.225 & 0.472 & 0.001 & $-0.743 *$ & $-0.762 *$ & 0.230 & & -0.606 & 0.000 & 0.215 & 0.030 \\
\hline Fruit length & 0.220 & -0.112 & 0.370 & -0.009 & -0.063 & 0.154 & -0.022 & -0.044 & 0.006 & -0.055 & 0.125 & 0.164 & & 0.395 & -0.157 & -0.119 \\
\hline No. of seeds per pod & 0.137 & 0.197 & 0.302 & 0.402 & 0.027 & 0.540 & 0.403 & 0.170 & -0.340 & -0.283 & 0.056 & $0.654 *$ & 0.275 & & -0.562 & -0.453 \\
\hline Seed index & 0.024 & -0.065 & -0.151 & -0.159 & -0.128 & -0.544 & -0.464 & -0.344 & 0.257 & 0.146 & -0.051 & -0.467 & -0.141 & $-0.886^{*}$ & & 0.247 \\
\hline Fruit yield per plant & 0.481 & -0.196 & 0.429 & -0.462 & $-0.743^{*}$ & 0.070 & $-0.698^{*}$ & -0.032 & $0.848 *$ & $0.916^{*}$ & -0.262 & -0.445 & 0.060 & -0.010 & -0.053 & \\
\hline
\end{tabular}

*significant at $5 \%$ level of significance 
Fig.1 Factor loadings of variables on PC 1 and PC 2 axes

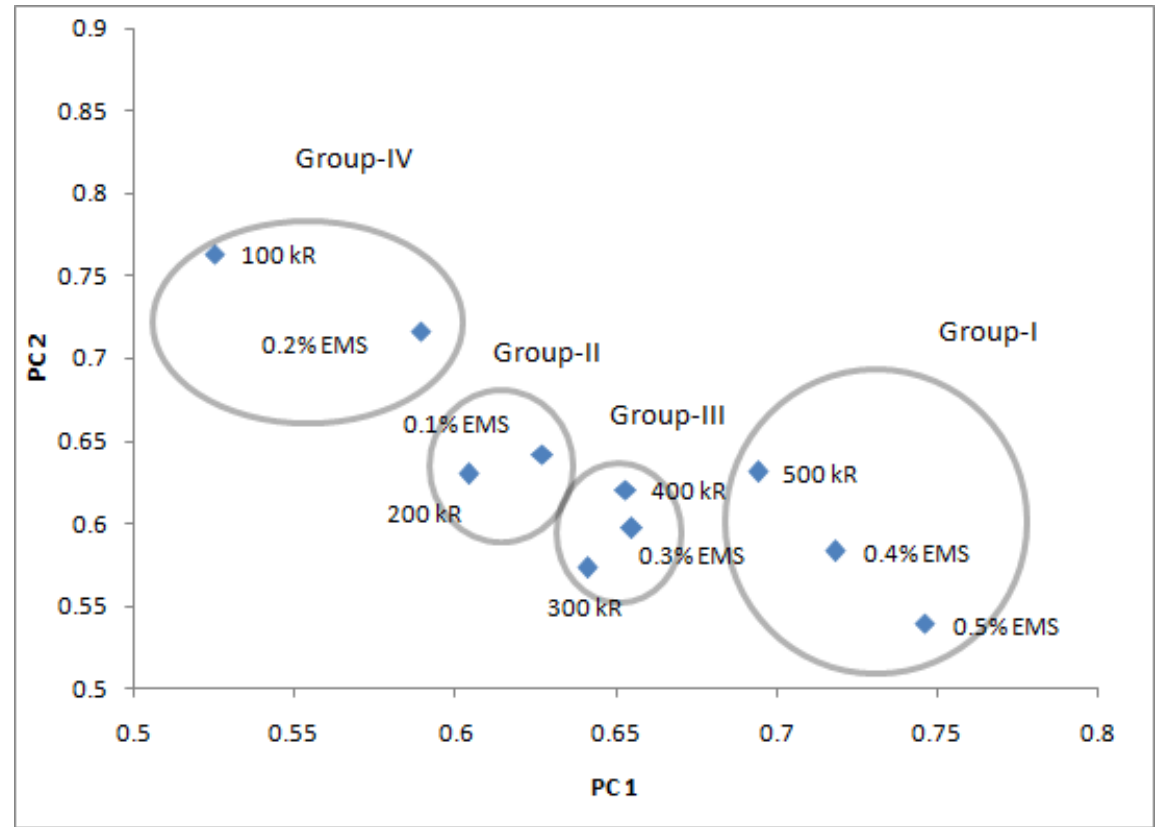

Fig.2 Ward's dendrogram constructed by using mean values $1=100 \mathrm{kR} \gamma ; 2=200 \mathrm{kR} \gamma ; 3=300 \mathrm{kR} \gamma ; 4=400 \mathrm{kR} \gamma ; 5=500 \mathrm{kR} \gamma ; 6=0.1 \%$ EMS; $7=0.2 \%$ EMS; $8=0.3 \%$ EMS' $9=0.4 \%$ EMS; $10=0.5 \%$ EMS

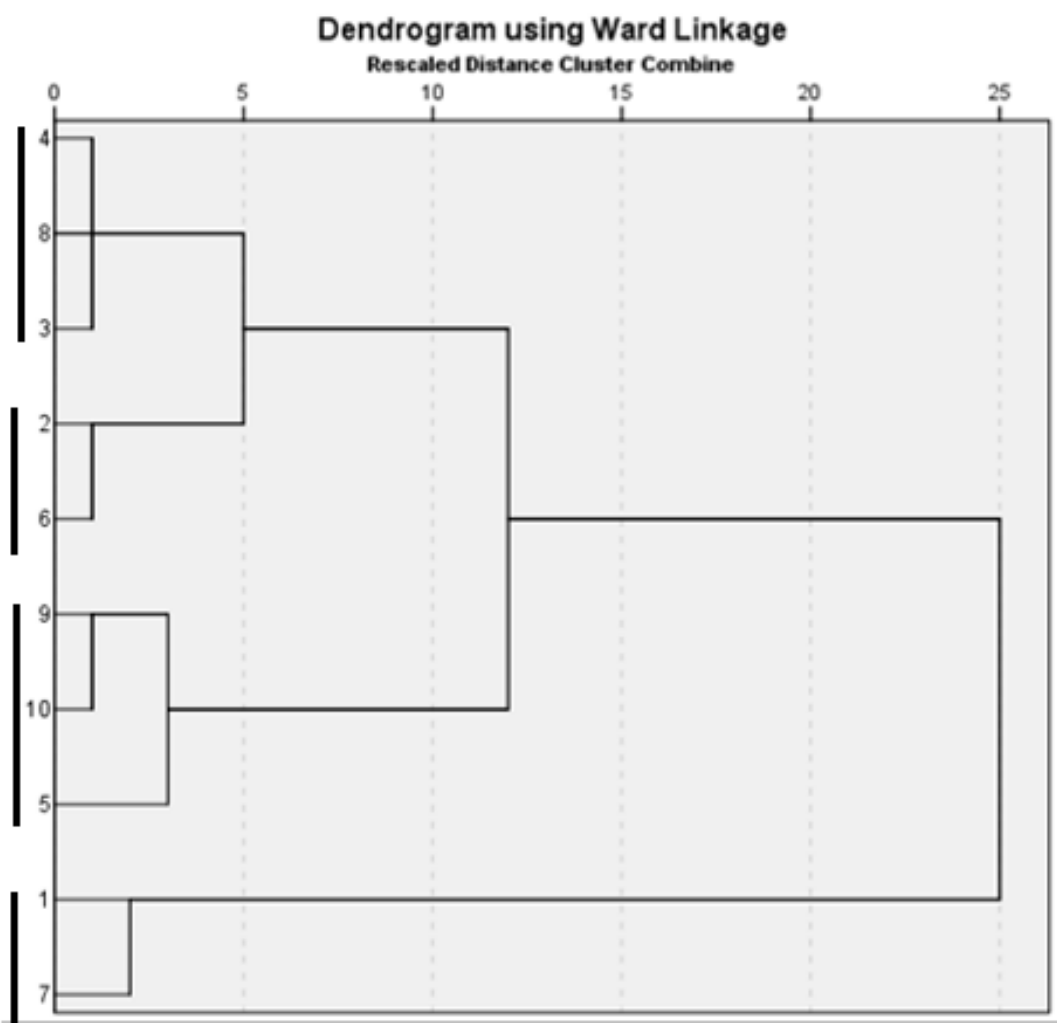


High GAM was observed for number of primary branches/plant when treated with gamma radiation and for fruit length when soaked in EMS. Moderate GAM vales were observed for germination percentage, plant height at 60 DAS, days to first fruit set and number of epicalyx segments when treated with gamma radiation and for fruit length when soaked in EMS. Moderate GAM was recorded for number of primary branches/plant when soaked in EMS and for fruit length when treated with gamma radiation. Low GAM was found for plant height at 25 DAS and fruit weight when soaked in EMS.

High GAM for average fruit length, fruits per plant and fruit weight were observed in an $\mathrm{M}_{2}$ generation in okra by Suryakumari (2002). Moderate to high GAM was observed for number of branches per plant and fruit yield per plant in $\mathrm{M}_{2}$ generation of okra when treated with gamma radiation and EMS and low to moderate GAM was observed for plant height, number of nodes on main stem, internodal length, fruit length, fruit diameter, fruit weight, number of seeds per fruit, number of fruits per plant by Reddy and Dhaduk (2014). High heritability coupled with high GAM was observed for days to first flower set, first node to flower, first node to fruit, number of flowers per plant, number of fruits per plant, number of seeds per pod, seed index and fruit yield per plant in both the populations and for number of primary branches/plant when treated with gamma radiation; for fruit length when soaked in EMS suggesting that these characters were under strong influence of additive gene action. Hence, simple selection can be followed for the improvement of these traits.

High heritability and genetic advance were observed for yield per plant, plant height, number of seeds per fruit and number of fruits per plant in a gamma radiation and EMS- induced okra population by Singh et al., (1998). High heritability associated with high GAM was observed earlier for average fruit length, fruits per plant and fruit weight in $\mathbf{M}_{2}$ generation in okra by Suryakumari (2002). High heritability with high genetic advance was found for yield per plant, plant height and number of seeds per fruit in EMS-induced $\mathrm{M}_{2}$ and $\mathrm{M}_{3}$ generations for all genotypes by Singh and Singh (2004).

In the present study, high heritability joined with low GAM was observed for the traits viz., plant height at 25 DAS and fruit weight when soaked in EMS indicating that these traits were governed by the non-additive gene action, and these traits could be improved by exploiting heterosis. It indicates the role of environment in the expression of the traits. Selection in later generations after these traits are stabilised in the population would be effective in recovering desired genotype (Reddy and Dhaduk, 2014).

The degree of association between characters was measured by calculating the Pearson correlation coefficients between the characters in case of both gamma radiation and EMS soaking treatments, and the same has been presented in table 3. In both the population positive association of fruit yield per plant was observed with number of flowers per plant and number of fruits per plant while a negative association was found for days to first flower set and first fruiting node in case of gamma ray induced mutagenic population suggesting the consideration of these characters while selecting high yielding genotypes. Strong positive correlation of yield per plant with number of fruits per plant, fruit length, fruit girth, number of seeds per fruit and plant height was previously observed in a gamma radiated, and EMS treated combined population in okra by Singh et al., (1998). Days to first flower set was having a negative association with number of flowers per plant, 
number of fruits per plant, germination percentage and plant height at 60 DAS whereas the positive association with the first node to flower in both the cases. Number of flowers per plant and number of fruits per plant were having a positive association in both the cases and in turn both had a negative association with days to first flower set, days to first fruit set and fruit weight in gamma induced population. Number of seeds per pod was found to have a positive association with fruit weight and negative association with seed index in gamma induced population. Germination percentage had number of correlations in the case of EMS-induced mutagenic population such as positive association with plant height at 25 DAS, plant height at 60 DAS, days to first fruit set, first fruiting node and number of seeds per pod. In this case number of seeds per pod was having a positive association with days to first fruit set and the first node to fruit.

It can be concluded from the present experiment that both the mutagens induced more variation at higher doses than at their lower doses. There was no greater difference between two mutagenic agents namely gamma radiation and EMS regarding mean performance for various characters. Gamma radiation induced higher variation for important yield components like plant height, branches per plant, number of fruits per plant and fruit weight while EMS-induced higher variation for earliness characters like germination percentage, days to first flower set and days to first fruit set. High heritability was found high for almost all the characters in case of both gamma radiation and EMS soaking. Additive gene action revealed by high heritability and high GAM was found for all the important yield components like days to first flower set, first node to flower, first node to fruit, number of flowers per plant, number of fruits per plant, number of seeds per pod, seed index and fruit yield per plant suggesting that both the mutagenic agents induced simple selectable heritable variation which can be exploited through simple selection. Positive association of fruit yield per plant with number of flowers per plant and number of fruits per plant and negative association with days to first flower set and first fruiting node in both populations suggesting importance of these characters while selecting high yielding genotypes.

\section{Acknowledgement}

The first and second authors are highly thankful to the Department of Science and Technology, Government of India for financial assistance through INSPIRE fellowship.

\section{References}

Anonymous. 2000. Agro-export statistics. Agriculture and Processed Food Export Development Agency, New Delhi.

Anonymous 2015. Indian Horticulture Database 2014, National Horticulture Board, Ministry of Agriculture, Government of India, Gurgaon, New Delhi.

Burton, G.W. 1952. Quantitative inheritance in grasses. Proc. Inter Grassland Cong. 1: $277-83$.

Dhankhar, B.S. and Dhankhar, S.K. 2003. Effect of gamma rays in okra. Haryana J. Horti. Sci. 32: 296.

Gower, J.C. 1966. Some distance properties of latent and vector methods used in multivariate analysis. Biometrika. 53: 325-338.

Hanson, C.H., Robinson, H.F. and Comstock, R.E. 1956. Biometrical studies of yield in segregating population of Kreanlespedse. Agron. J. 48: 267-282.

Jadhav, P.A., Kalpande, H.V., Abad, S.K. and Mali, A.R. 2013. Induced mutagenesis 
in okra [Abelmoschus esculentus (L.) Moench] by gamma rays and ethyl methane sulphonate. Veg. Sci. 40(2): 223-224.

Jadhav, P.A., Kalpande, H.V., Kathale, M.N. and Dahale, G.P. 2012. Effect of gamma rays and ethyl methane sulphonate on germination, pollen viability and survival of okra [Abelmoschus esculentus (L.) Moench]. J. Crop Weed. 8(2): 130131.

Johnson, H.W., Robinson, H.F. and Comstock, R.E. 1955. Estimates of genetic and environmental variability in soybean. Agron. J. 47: 314-318.

Kashid, N.G. and Kulthe, M.P. 2014. Effect of physical and chemical mutagens on pod length in Okra (Abelmoschus esculentus (L.) Moench). Sci. Res. Report. 4(2): 151-154.

Reddy, P.S. and Dhaduk, L.K. 2014. Induction of genetic variability in okra [Abelmoschus esculentus
Moench] by gamma and EMS. Elec. J. Pl. Breed. 5(3): 588-593.

Singh, A.K. and Singh, K.P. 2004. Induced quantitative variation for yield and its components in okra [Abelmoschus esculentus (L.) Moench]. Indian J. Horti. 61(3): 240-244.

Singh, A.K., Singh, K.P. and Singh, V.P. 1998. Genetic analysis of induced mutants of okra [Abelmoschus esculentus (L) Moench]. Veg. Sci. 25(2): 174-177.

Singh, R.K. and Chaudhury, R.D. 1985. Biometrical methods of quantitative genetic analysis. Kalyani Publishers, Ludhiana.

Suryakumari, S. 2002. Induced polygenic mutations in okra [Abelmoschus esculentus (L.)Moench]. South Indian Horti. 50: 533-537.

Ward, J.H. 1963. Hierarchical grouping to optimize an objective function. J. Americ. Stat. Assoc. 58: 236-244.

\section{How to cite this article:}

Rajkumari Ashadevi, A.V.V. Koundinya and Chattopadhyay, S.B. 2017. An Estimation of Effective Mutagen Doses, Induced Genetic Variation and Characters Association in $\mathrm{M}_{2}$ Generation of Okra. Int.J.Curr.Microbiol.App.Sci. 6(5): 2209-2219. doi: https://doi.org/10.20546/ijcmas.2017.605.247 